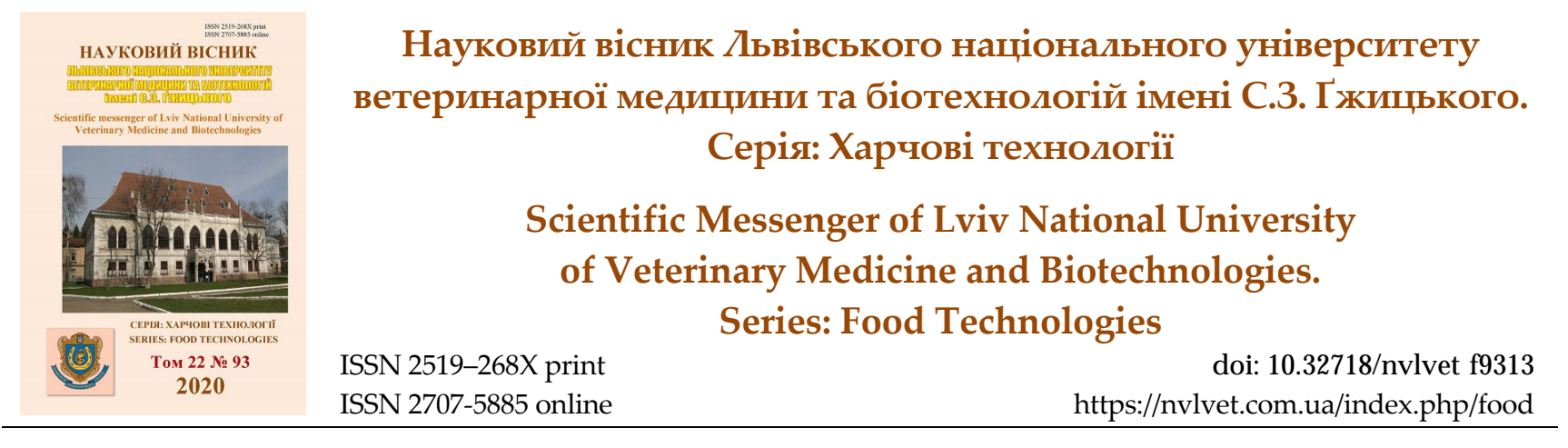

UDC 637.55:338.439

\title{
Expanding the range of sausage products of special purpose
}

\author{
O. Haschuk ${ }^{1}$, O. Moskalyuk ${ }^{1}$, I. Simonova ${ }^{2}$ \\ ${ }^{1}$ National University of Food Technology, Kyiv, Ukraine \\ ${ }^{2}$ Stepan Gzhytskyi National University of Veterinary Medicine and Biotechnologies Lviv, Ukraine
}

Article info

Received 11.02.2020

Received in revised form 12.03 .2020

Accepted 13.03.2020

National University of Food Technology, Volodymyrska Str., 68 Kyiv, 01601, Ukraine.

Tel.: +38-067-286-84-35 +38-097-796-95-90 E-mail: ohaschuk@ukr.net MoskalyukOE@i.ua

Stepan Gzhytskyi National University of Veterinary Medicine and Biotechnologies Lviv, Pekarska Str., 50, Lviv, Ukraine. Tel.: +38-096-484-69-9! E-mail: ira.markovuch@gmail.com
Haschuk O., Moskalyuk O., \& Simonova I. (2020). Expanding the range of sausage products of special purpose. Scientific Messenger of Lviv National University of Veterinary Medicine and Biotechnologies. Series: Food Technologies, 22(93), 72-76. doi: 10.32718/nvlvet-f9313

The article presents the results of research of minced meat from turkey meat with the addition of whole blood in order to expand the range of special purpose products. The presence of a wide range of physiologically active substances in meat raw materials determines its special properties. In scientific work was conducted influence of products of blood processing on qualitative indicators of sausages of healthimproving purposes. The use of blood protein Globin Vepro Gel $95 \mathrm{HV}$ in the composition of protein-fat emulsion (in the amount of $40 \%$ by weight of minced meat) and whole blood to increase the iron content in the product for the prevention and treatment of anemia. During the organoleptic evaluation of meat systems, it was found that partial replacement of raw meat in minced meat with whole blood has a beneficial effect on the color of the product. But with the increase in the amount of blood there is a deterioration of organoleptic parameters. The addition to the minced meat of a protein-fat emulsion based on globin protein and the addition of whole blood in appropriate proportions creates the conditions for moisture binding. However, with the addition of $10 \%$ of blood, there is a decrease in moisture binding capacity by $0.3 \%$. According to the results of studies of the content of essential amino acids, it was found that the experimental samples of sausages are characterized by the content of complete proteins. In particular, the sample № 3, which has the best functional and technological indicators has a higher rate of Lysine, Leucine, Methionine + Cysteine, Valine compared to the control sample. The dominant amino acids are Lysine, Threonine, Leucine, Phenylalanine and Tyrosine, Limiting - Methionine, Cystine, Valine, Isoleucine. For sample № 3, the value of the utilization coefficient of the protein is 0.52 , the biological value is $61.12 \%$.

Key words: turkey meat, whole blood, protein-fat emulsion, sausages.

\section{Розширення асортименту ковбасних виробів спеціального призначення}

\author{
О. І. Гащук ${ }^{1}$, О. Є. Москалюк ${ }^{1}$ I. І. Сімонова ${ }^{2}$
}

${ }^{1}$ Національний університет харчових технологій, м. Київ, Украӥна

${ }^{2}$ Львівський національний університет ветеринарной медицини та біотехнологій імені С. З. Гжицького, м. Львів, Украӥна

У статті наведено результати досліджень модельних фаршів з м'яса індиків з додаванням цільної крові з метою розиирення асортименту продуктів спеціального призначення. Наявність у м'ясній сировині біологічно активних речовин иирокого спектру фізіологічної дії визначає його спеціальні властивості. У науковій роботі проведено дослідження впливу продуктів переробки крові на якісні показники сосисок оздоровчо-профілактичного призначення. Запропоновано використання білку крові Глобін Иерго Gеl 95 HV у складі білково-жирової емульсії (у кількості 40 \% до маси фаршу) та иільну кров з метою підвищення вмісту заліза у продукті для профілактики та лікування анемї. Під час проведення органолептичної оцінки м'ясних систем встановлено, щзо часткова заміна м'ясної сировини у фарші на иільну кров сприятливо впливає на колір продукту. Але із збільшенням кількості крові спостерігається погіршення органолептичних показників. Додавання до фаршу білково-жирової емульсї на основі білка глобіну та додавання иільної крові у відповідних співвідношеннях створює умови до зв'язування вологи. Однак з додаванням крові у кількості 10 \% спостерігається зменшення вологозв'язуючої здатності на 0,3\%. За результатами досліджень вмісту незамінних амінокислот встановлено, що експериментальні зразки сосисок характеризуються вмістом повноцінних білків. Зокрема зразок № 3, який воло- 
діє найкращчим функиіонально-технологічними показниками має вищий показник СКОР лізину, лейцину, метіоніну+цистеїну, валіну у порівнянні з контрольним зразком. Домінуючими амінокислотами є лізин, треонін, лейцин, фенілаланін та тирозин, лімітуючими - метіонін, цистин, валін, ізолейцчин. Для зразка № 3 значення коефіцієнта утилітарності білка - 0,52, біологічна изінність $-61,12 \%$.

Ключові слова: м'ясо індиків, циільна кров, білково-жирова емульсія, сосиски.

Вступ

До продуктів спеціального призначення відносять дієтичні, лікувально-профілактичні, геродієтичні продукти харчування, продукти харчування для дітей, спортсменів, космонавтів, людей, які працюють в екстремальних умовах (Kaprelyants, 2004; Bohrer, 2017). До дієтичного, профілактичного харчування або дієтотерапії відносяться продукти харчування, які застосовуються при різних захворюваннях, які в комплексі з лікувальними заходами сприяють відновленню життєвих функцій організму хворого (De Sme \& Vossen, 2016; Brenes et al., 2016).

Саме м'ясо можна розглядати як продукт спеціального призначення (Alamprese et al., 2016; Shan et al., 2017). Наявність у м'ясній сировині біологічно активних речовин широкого спектру фізіологічної дії, таких як біоактивні пептиди, мінеральні речовини (цинк, залізо, селен), вітаміни, жирні кислоти, харчові волокна й інші визначає його спеціальні властивості: поліпшення загального стану організму, стимулювання активності ферментів, системи детоксикації й антиоксидантного захисту, підвищення імунного потенціалу і резистентності (Wang et al., 2016; Haschuk et al., 2020).

Ринок продуктів спеціального призначення постійно розширюється. Необхідність задоволення зростаючих потреб споживачів у якісних і різноманітних спеціальних продуктах вимагає від виробників розширення сировинної бази (Drachuk et al., 2018; Haschuk \& Moskalyuk, 2020).

\section{Матеріал і методи досліджень}

При розробленні рецептури сосисок обрано м'ясо індиків, білок крові Глобін Vepro Gel 95 HV у складі білково-жирової емульсії (БЖЕ) та цільна кров $з$ метою підвищення вмісту заліза для профілактики та лікування анемії.

В роботі визначали органолептичні функціонально-технологічні, структурно-механічні показники та біологічна цінність продукту.

Органолептичне оцінювання якості ковбасних виробів здійснювалося за 5-бальною шкалою. До основних показників якості ковбасних виробів, які визначалися при оцінюванні, належать: зовнішній вигляд, вид і колір на розрізі, аромат, смак, консистенцію.

pH середовища визначали потенціометричним методом на лабораторному РН-метрі. Метод грунтується на вимірюванні електрорушійної сили елемента, який складається із електроду порівняння 3 відомою величиною потенціалу та індикаторного (скляного) електроду, потенціал якого обумовлений концентрацією іонів водню в досліджуваному розчині. Визначення проводили у відфільтрованій водній витяжці при співвідношенні продукту і води 1:10
Було досліджено структурно-механічні властивості фаршів: ефективну в'язкість та граничне напруження зсуву. Вимірювання динамічної в'язкості проводили за допомогою ротаційного віскозиметра "Реотест 2" в циліндричному вимірювальному пристрої. Вони виявляються під час підведення механічної енергії до продукту, що обробляється, і характеризують його опірність прикладеним ззовні механічним діям

Визначення амінокислотного складу проводилося у відповідності з методом іонообмінної хроматографії на автоматичному аналізаторі амінокислот Т 339, виробництво "Мікротехніка", Чехія. Визначення амінокислотного СКОРу є індексом біологічної цінності білків. Метод розрахунку амінокислотного СКОРу зводиться до визначення відношення вмісту кожної незамінної амінокислоти в досліджуваному білку до їх вмісту у стандарті - еталоні, збалансованому за незамінними амінокислотами i рекомендованому комітетом ФАО/ВООЗ.

\section{Результати та їх обговорення}

Під час проведення органолептичної оцінки м'ясних систем залежно від досліджуваних факторів, встановлено, що використання білка глобіну краще впливає на консистенцію продукту порівняно 3 контрольним зразком. Часткова заміна м'ясної сировини у фарші на цільну кров сприятливо впливає на колір продукту. Але у зразках № 5, № 6 та № 7 із збільшенням кількості крові спостерігається погіршення органолептичних показників. Враховуючи результати органолептичної оцінки фаршевих систем подальші дослідження проводили із зразками № 1, № 2, № 3 та № 4 .

Визначення функціонально-технологічних показників модельних фаршів дає повну уяву про м'ясну систему, iї структуру, здатність поглинати та утримувати вологу під час теплової обробки, що дозволяє прогнозувати та направлено регулювати якісні характеристики готових продуктів. Функціональнотехнологічні показники модельних м'ясних фаршів представлені в табл. 1.

За результатами експериментальних досліджень встановлено, що додавання до фаршу білково-жирову емульсію 3 використанням білка глобіну та цільної крові у відповідних співвідношеннях створює умови до зв'язування вологи до певної точки. Так, вологозв'язуюча здатність у дослідних зразках № 1, № 2, № 3 збільшувалась, у порівнянні зі контрольним зразком, однак у зразку № 4, 3 додаванням крові у кількості $10 \%$ спостерігається зменшення показника В33 на $0,3 \%$, у порівнянні зі зразком № 3 , В33 якого є найбільшим і становить 83,4 \%. Вологозв'язуюча здатність м'ясних продуктів забезпечується вмістом білків, які є структурними i функціональними елементами м'язової тканини і мають властивості поверхнево- 
активних речовин. У м'ясних системах білки беруть участь в утворенні водної матриці фаршу і емульгуванні жиру.
На рисунку 1 представлена порівняльна характеристика показників стійкості емульсії (CE) та емульгуючої здатності (Е3) модельних м’ясних фаршів.

Таблиця 1

Функціонально-технологічні показники модельних м’ясних фаршів

\begin{tabular}{|c|c|c|c|c|c|}
\hline Показники & Контроль & Зразок №1 & Зразок №2 & Зразок №3 & Зразок №4 \\
\hline $\mathrm{pH}$ & $6,1 \pm 0,1$ & $6,2 \pm 0,1$ & $6,2 \pm 0,1$ & $6,2 \pm 0,1$ & $6,2 \pm 0,1$ \\
\hline В33 до загальної вологи, \% & $75,11 \pm 0,11$ & $80,22 \pm 0,32$ & $82,33 \pm 0,36$ & $83,44 \pm 0,31$ & $83,11 \pm 0,22$ \\
\hline В33 до маси сировини, \% & $65,01 \pm 0,41$ & $67,37 \pm 0,34$ & $68,34 \pm 0,44$ & $69,04 \pm 0,39$ & $68,88 \pm 0,27$ \\
\hline Стійкість емульсії & $56,8 \pm 0,5$ & $75,5 \pm 0,4$ & $73,4 \pm 0,5$ & $74,4 \pm 0,8$ & $72,1 \pm 0,1$ \\
\hline Емульгуюча здатність & 59,0 & 60,0 & 62,0 & 62,0 & 60,0 \\
\hline
\end{tabular}

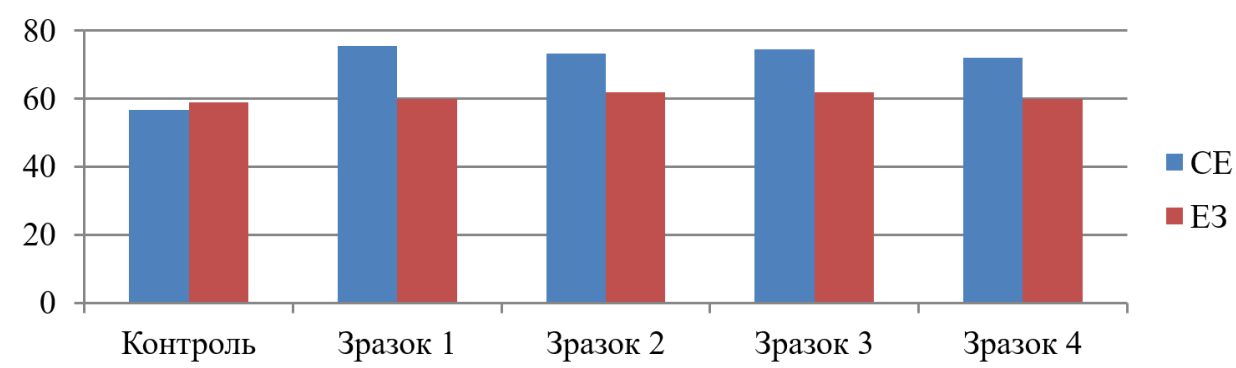

Рис. 1. Стійкість емульсії та емульсійна здатність модельних м'ясних фаршів

Дослідні дані свідчать про значне збільшення стійкості емульсії та емульгуючої здатності фаршів при додаванні БЖЕ у порівнянні з контрольним зразком. Зокрема, якщо контрольний зразок мав показник CE 56,8 \%, то зразок № 1 має цей показник на рівні $75,5 \%$, а Е3 у контрольного зразка $59 \%$, в зразках № 2 та № 3 ця характеристика сягає $62 \%$.

Було досліджено структурно-механічні властивості фаршів: ефективну в'язкість та граничне напружен- ня зсуву. Структурно-механічні (реологічні) властивості продукту $є$ фундаментальними фізичними властивостями тіла. Вони виявляються під час підведення механічної енергії до продукту, що обробляється, i характеризують його опірність прикладеним ззовні механічним діям. Графік залежності ефективної в’язкості від маси навантаження наведено рис. 2.

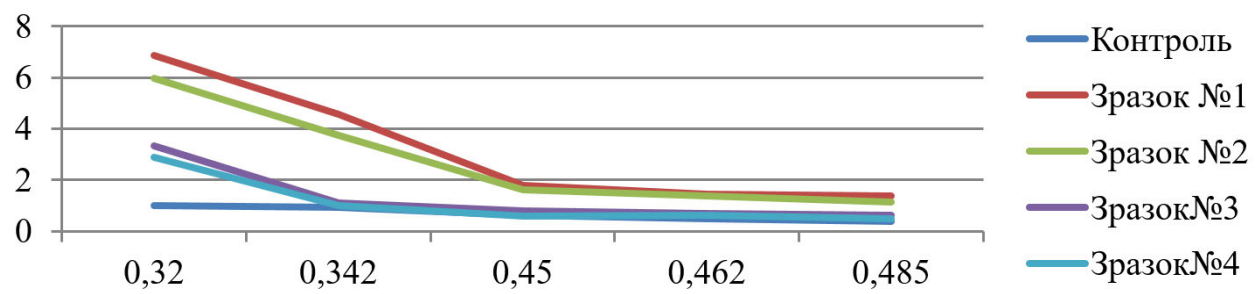

Рис. 2. Залежність ефективної в'язкості модельних м'ясних фаршів від маси навантаження

Отже, за результатами досліджень органолептичних, функціонально-технологічних і структурно-механічних показників для розробки рецептури сосисок профілактичного призначення 3 додаванням цільної крові були обрані зразки № 2, 3 .

3 метою обгрунтування підвищення біологічної цінності розроблених сосисок 3 додаванням м'яса індиків, БЖЕ та цільної крові у порівнянні з сосисками, виготовленими за традиційною технологією, нами було проведено розрахунок вмісту незамінних амінокислот у зразках, які мали найкращі функціональнотехнологічні показники - № 2 та № 3. Дані амінокислотного СКОРу, отриманого розрахунковим способом наведено на рис. 3.

За результатами досліджень встановлено, що зразки сосисок характеризуються вмістом повноцінних білків із набором необхідних для людини амінокислот (рис. 3). Спостерігається зменшення ізолейцину зі збільшенням вмісту крові в продукті. Зокрема зразок № 3, який володіє найкращими функціональнотехнологічними показниками має вищий показник СКОР лізину, лейцину, метіоніну+цистеїну, валіну у порівнянні 3 контрольним зразком. Домінуючими амінокислотами $є$ лізин, треонін, лейцин, фенілаланін та тирозин, лімітуючими - метіонін, цистин, валін, ізолейцин.

Об’єктивну оцінку біологічної цінності білків визначали за комплексом показників: амінокислотний скор, коефіцієнт різниці амінокислотного скору (КРАС), коефіцієнт утилітарності (U).

Для оцінки ступеня використання білка розраховували коефіцієнт різниці амінокислотного скору (КРАС) - це різниця амінокислотного СКОРу незамінних амінокислот і СКОРу амінокислоти, що лімітує. 


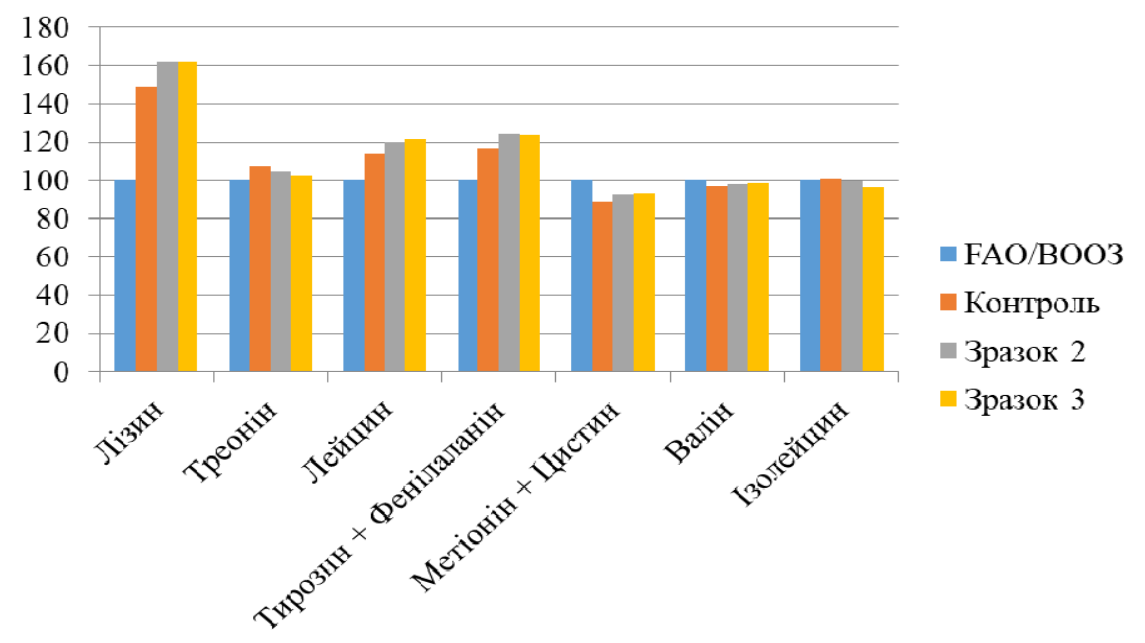

Рис. 3. Амінокислотний СКОР розроблених рецептур сосисок, \%

Таблиця 2

Показники біологічної цінності готового продукту

\begin{tabular}{lccc}
\hline \multicolumn{1}{c}{ Показники } & Контроль & Зразок 2 & Зразок 3 \\
\hline КРАС, \% & 43,41 & 42,67 & 38,88 \\
БЦ, \% & 55,44 & 57,33 & 61,12 \\
$\begin{array}{l}\text { Коефіцієнт утилітарності амінокислотного } \\
\text { складу, U }\end{array}$ & 0,35 & 0,49 & 0,52 \\
\hline
\end{tabular}

Результати розрахунків КРАС, біологічна цінність (БЦ) та коефіцієнту утилітарності (U) амінокислотного складу продукту представлені у таблиці 2.

КРАС показує середню міру надлишку амінокислотного СКОРу незамінних амінокислот порівняно 3 найменшим рівнем СКОРу будь-якої амінокислоти. Для еталонного білка він дорівнює 0. Біологічна цінність харчового білка - величина зворотна до КРАС, для еталонного білка вона дорівнює 100 \%. Біологічна цінність зразка № 2 становить 57,33\%, зразка № 3 $61,12 \%$.

Збалансованість незамінних амінокислот за співвідношенням до фізіологічно необхідної норми чисельно характеризується коефіцієнтом утилітарності $(\mathrm{U})$, який в ідеальному випадку дорівнює 1. Чим ближче показник до 1, тим більша можливість утилізації білка. Значення коефіцієнта утилітарності білка для зразка № 2 становить 0,49, а для зразка № $3-0,52$.

Отже, за результатами дослідження біологічної цінності кращі результати показав зразок № 3 .

\section{Висновки}

За результатами досліджень органолептичних, функціонально-технологічних і структурно-механічних показників розроблена рецептура сосисок спеціального призначення $з$ додаванням цільної крові у кількості 7 \% до маси фаршу (зразок № 3). Значення коефіцієнта утилітарності білка становить 0,52, біологічна цінність $-61,12 \%$.

\section{References}

Alamprese, C., Amigo, J. M., Casiraghi, E., \& Engelsen, S. B. (2016). Identification and quantification of turkey meat adulteration in fresh, frozen-thawed and cooked minced beef by FT-NIR spectroscopy and chemometrics. Meat Science, 121, 175-181. doi: 10.1016/j.meatsci.2016.06.018.

Bohrer, B. M. (2017). Review: Nutrient density and nutritional value of meat products and non-meat foods high in protein. Trends in Food Science \& Technology, 65, 103-112. doi: 10.1016/j.tifs.2017.04.016.

Brenes, A., Viveros, A., Chamorro, S., \& Arija, I. (2016). Use of polyphenol-rich grape by-products in monogastric nutrition.A review. Animal Feed Science and Technology, 211, 1-17. doi: 10.1016/j.anifeedsci.2015.09.016.

De Sme, S., \& Vossen, E. (2016). Meat: The balance between nutrition and health. A review. Meat Science, 120, 145-156. doi: 10.1016/j.meatsci.2016.04.008.

Drachuk, U., Simonova, I., Halukh, B., Basarab, I., \& Romashko, I. (2018). The study of lentil flour as a raw material for production of semi-smoked sausages. Eastern-european journal of enterprise technologies, 6, 11(96), 44-50. doi: 10.15587/1729-4061.2018.148319.

Haschuk, O. I., Moskalyuk, O. E. Gryshhenko, A., \& Guralevych, A. (2020). Development of meat products for special nutrition. Innovative development of hotel and restaurant industry and food production: Materials of the I International scientific-practical. internet conference - Prague: Oktan Print s.r.o., 29-30.

Haschuk, O., \& Moskalyuk, O. (2020). Use of blood in meat products of special food. The 18th International Scientific and Practical Conference "Modern Science, Practice, Society", Boston, USA, 248-250.

Kaprelyants, L. B (2004). Functional food: current status and development prospects. Products and ingredients, $1,22-24$.

Shan, L. C., De Brún, A., Henchion, M., Celine, C., Li, Patrick, M., Wall, G., \& Monahan, F. J. (2017). Consumer 
evaluations of processed meat products reformulated to be healthier - A conjoint analysis study. Meat Science, 131, 82-89. doi: 10.1016/j.meatsci.2017.04.239.

Wang, H. L., Chou, C. H., Yu, Y. S., Hsu, C. L., Wang, S. Y., Ko, Y. F., \& Chen, Y. C. (2016). Chicken surimi fortified by omega-3-fatty-acid addition: manufacturing and quality properties. J Sci Food, 96, 1609-1617. doi: $10.1002 /$ jsfa. 7262 . 